\section{Long-term trends of potential years of life lost due to main causes of death in the Slovak population, 2004-2013}

\author{
Tendências a longo prazo nos anos potenciais \\ de vida perdidos devido às principais causas de \\ óbito na população da Eslováquia, 2004-2013
}

\section{Tendencias a largo plazo de los años potenciales perdidos de vida, debido a las principales causas de muerte en la población eslovaca, 2004-2013}

\begin{abstract}
The aim of this study was to evaluate trends of potential years of life lost (PYLL) rates in the Slovak population and analyze the average annual percent change (AAPC) of PYLL rates regarding the most common causes of death between 2004 and 2013. National mortality and demographic data were obtained from the Statistical Office of the Slovak Republic, and 378,535 causes of death within the period were analyzed. The PYLL values in both genders and each disease category were added up across all age groups to form annual values. For the trend analysis, the AAPC indicator was proposed. The PYLL rate is age-standardized and expressed as a sum of all deaths per 100,000. In the period 2004-2013, the highest mean PYLL rates were observed in neoplasms in the whole population $(2,103$ per 100,000), as well as in females $(2,088$ per 100,000), with a permanent high significant increase of AAPC of PYLL in both genders. The second highest mean PYLL rate in the ten-year period was related to circulatory system diseases in total $(1,922$ per 100,000) as well as in females (1,449 per 100,000). In males, circulatory system diseases had the highest PYLL rate $(2,397$ per 100,000$)$. The PYLL rates trend regarding external causes of morbidity and mortality showed the most notable decrease in the assessed period and the AAPC of PYLL showed significant negative values both in males $(-2.5 \% ; p<0.001)$ and females $(-4 \% ; p<0.001)$. Our results should contribute in developing intervention programs aimed at reducing the burden of premature mortality since the main causes of premature death are associated to well-known and preventable risk factors.
\end{abstract}

Potential Years of Lost Life; Trends; Premature Mortality; Causes of Death
Martin Samohyl 1

Lubica Argalasova 1

Katarina Hirosova 1

Jana Jurkovicova 1

doi: $10.1590 / 0102-311 \times 00052218$

\author{
Correspondence \\ M. Samohyl \\ Institute of Hygiene, Faculty of Medicine, Comenius University. \\ 24 Spitalska, Bratislava 81372 , Slovakia. \\ martin.samohyl@fmed.uniba.sk \\ 1 Faculty of Medicine, Comenius University, Bratislava, Slovak \\ Republic.
}




\section{Introduction}

Premature mortality is a measure of unfulfilled life expectancy and the premature mortality rate is then determined by adding up the potential life lost years of individuals in each country ${ }^{1}$. In epidemiological research there are different definitions of premature mortality, however, premature death is defined as death that occurs before the average age of death in a certain population; usually as death before 70 years of age (e.g. in the Organisation for Economic Co-operation and Development - OECD - countries) 2,3,4. It allows the time trends analysis, but does not include the social and economic burdens of premature deaths imposed on society. Therefore, the concept of potential years of life lost (PYLL) involving premature deaths was introduced, which includes the number of deaths resulting from a particular cause, as well as the age at death and allows weighting potentially preventable deaths occurring at younger ages 5,6.

PYLL can incorporate information about the general population experience when investigating the burden of a particular condition. PYLL rate measures the difference in life expectancy between patients with a particular condition and people with similar characteristics in the general population. It provides a direct assessment of disease-related mortality and allows separating gender and race differences in mortality from selected diseases from the background of gender and race differences in those general populations 7 .

The Slovak Republic is one of those countries where a long-term trend of population ageing can be observed. Population ageing is influenced by a gradually increase of life expectancy at birth, which in 2013 (according to OECD data) reached the age of 72.9 years for males and 80.1 years for females. Compared to 2004, this represents an increase of 2.6 years in males and of 2.1 years in females 8 . However, Slovakia is one of the lowest ranked among OECD countries 9 .

In 2016, age-standardized mortality rate (per 100,000) was 733.7 in Central Europe (Ukraine: 1,022.0; Slovakia: 747.8; Austria: 499.0); 713.0 in Latin America and Caribbean; 791.6 in Southeast Asia, East Asia and Oceania; 841.4 in North Africa and Middle East; 1,178.0 in South Asia; and 1,371.0 in Sub-Saharan Africa 10.

In the Slovak Republic, the most common long-term causes of death are cardiovascular diseases (CVD) 11, malignant tumors, respiratory system diseases and external causes of death (road traffic injuries, accidental injuries) 9 . In 2013, the mortality rates for CVD were higher in females (57.4\%) than in males (43.6\%), while tumors mortality rates were higher in males than in females $(28.7 \%$ and $22.4 \%$, respectively). The third and fourth leading causes of death (respiratory diseases and external causes) comprise $7.1 \%$ and $7.9 \%$ from all male deaths, respectively; and $6.1 \%$ and $2.7 \%$ from all female deaths 12 .

The Slovakian total PYLL rate per 100,000 inhabitants aged 0-69 in 2004 was 8,311.7 (for men) and 3,555.8 (for women), and in $20146,379.4$ and 2,904.7, respectively 8 . This represents a decrease of total PYLL rate by 1,932.3 in men and by 651.1 in women. However, the numbers of studies in the Slovak Republic analyzing the PYLL rates concerning selected mortality causes are limited. As such, the aim of this study was to evaluate trends of PYLL rates in the Slovak population and analyze the average annual percent change (AAPC) of PYLL rates regarding the most common causes of death in the period 2004-2013.

\section{Methodology}

This study analyzed PYLL rates per 100,000 and AAPC of PYLL (\%) in a ten-year period (2004-2013) divided into two sub-periods (2004-2008 and 2009-2013) in the Slovak population aged 0-69 years old, because of neoplasms (C00-C97), circulatory system diseases (I00-I99), respiratory system diseases (J00-J99), digestive system diseases (K00-K93), nervous system diseases (G00-G99), endocrine, nutritional and metabolic diseases (E00-E90), external causes of morbidity and mortality (V01-Y98), congenital malformations, deformations and chromosomal abnormalities (Q00-Q99), and symptoms, signs and abnormal clinical and laboratory findings, not elsewhere classified (R00-R99). The PYLL rate was age-standardized and expressed as a sum of all deaths per 100,000. 
National mortality and demographic data were obtained from the Statistical Office of the Slovak Republic and 378,535 causes of death were analyzed.

Calculation of the PYLL rate ${ }^{13}$ was based on the following equation:

$$
P Y L L_{i t}=\Sigma(l-a)\left(d_{a t} / p_{a t}\right)\left(p_{a} / p_{n}\right) \times 100,000
$$

where $l$ represents the population's life expectancy, $a$ is age in one-year intervals, $d_{a t}$ is the number of deaths in a certain age group in each causes of death (i) during each year $(t), p_{a t}$ is the number of inhabitants in an age group, $p_{a}$ is the number of standard population in a certain age group and $p_{n}$ is the total number of standard population (0-69 years of age). The formula for PYLL calculating includes the age of 0-69 years, given the possibility of international comparison.

PYLL values in both genders and in each disease category were added up across all age groups to form annual values. For the trend analysis, the average annual percent change (AAPC) indicator 14 was proposed. Thus, the mean percentage difference of annual growth/decline was obtained using the following equation:

$$
A A P C=\frac{1}{n} \sum \frac{x_{i}-x_{i-1}}{x_{i-1}} \times 100
$$

where $x$ represents input vector of PYLL rate in period $\mathrm{n}$ in year $i$, in each analyzed period.

For statistical evaluation of the systematic change significance in each period, we used the TheilSen estimator 15 of trend line based on median and its significance was tested by nonparametric Wilcoxon test using statistical software R package - Median-Based Linear Model (mblm). The trend was considered significant if $\mathrm{p}$-value was $<0.05$. The calculations and figures were made in statistical software R (http://www.r-project.org).

\section{Results}

The AAPC of PYLL regarding selected causes of death and gender in specific periods are shown in Table 1. Ten-year trends of PYLL due to main causes of death in total can be seen in Figures 1 and 2.

In the period of 2004-2013, the highest mean PYLL rate observed in the total population (2,103 per 100,000) (Figure 1), as well as in females $(2,088$ per 100,000), was related to neoplasm. The highest PYLL rate for this disease (C00-C97) can be noticed in 2013 both in males and females (2,336 per 100,000 and 2,234 per 100,000, respectively). In this ten-year period, a permanent high significant increase of PYLL expressed as AAPC can be observed in both males and females $(\mathrm{p}<0.001)$ (Table 1).

Circulatory system diseases had the second highest mean PYLL rate in the ten-year period in total $(1,922$ per 100,000) (Figure 1), as well as in females $(1,449$ per 100,000), with the peak values in 2007 of 1,996 per 100,000 in males and 1,519 per 100,000 in females. The highest PYLL rate in this condition (I00-I99) was in males in the whole period $(2,397$ per 100,000), with peak value in $2012(2,481$ per $100,000)$. A significant increase of the AAPC of PYLL $(\mathrm{p}<0.01)$ during the entire period (2004-2013) can be observed in males, with a significant decrease of the AAPC of PYLL $(\mathrm{p}<0.01)$ in females in the same period (Table 1).

The PYLL rate trend concerning respiratory system diseases increased in the ten-year period in total (Figure 2), with the AAPC of PYLL showing significantly increase in total of $2.1 \%(\mathrm{p}<0.01)$. The increase is more pronounced in men $(2.5 \%$; $<<0.01)$, although in the sub-period of 2009-2013, the highest (3.6\%) but not significant AAPC was related to women (Table 1).

The PYLL rate for digestive system diseases had in the first sub-period (2004-2008) an upward trend in total (Figure 1), and the AAPC of PYLL values were significant (males $5.8 \%, \mathrm{p}<0.01$ and females $4.5 \%, \mathrm{p}<0.05)$. However, in the next sub-period $(2009-2013)$ the opposite trend noticed observed, significant in females: $-5.5 \%, \mathrm{p}<0.05$ (Table 1 ).

The PYLL rates concerning nervous system diseases, endocrine, nutritional and metabolic diseases, and congenital malformations had a fluctuating course in total (Figure 2) in the ten-year period, with no significant AAPC of PYLL (Table 1). 
Samohyl M et al.

\section{Table 1}

The average annual percent change (AAPC) of the potential years of life lost (PYLL) according to selected causes of death and gender in specific periods. Slovak Republic, 2004-2013.

\begin{tabular}{|c|c|c|c|}
\hline \multirow[t]{2}{*}{ Causes of death } & 2004-2008 & 2009-2013 & 2004-2013 \\
\hline & AAPC (\%) & AAPC (\%) & AAPC (\%) \\
\hline \multicolumn{4}{|l|}{ Neoplasms } \\
\hline Males & -0.2 & 2.8 * & 1.4 *** \\
\hline Females & 1.7 * & 0.8 & $1.5 * * *$ \\
\hline Total & 0.7 & 1.8 * & $1.4 * * *$ \\
\hline \multicolumn{4}{|c|}{ Diseases of the circulatory system } \\
\hline Males & 1.8 * & -0.8 & $0.7 * *$ \\
\hline Females & -1.1 & -2.2 & $-1.5 * *$ \\
\hline Both genders & 0.6 & $-1.3 *$ & -0.2 \\
\hline \multicolumn{4}{|c|}{ Diseases of the respiratory system } \\
\hline Males & 2.7 & 1.0 & $2.5 * *$ \\
\hline Females & 0.3 & 3.6 & 1.9 * \\
\hline Total & 1.6 & 1.9 & 2.1 ** \\
\hline \multicolumn{4}{|c|}{ Diseases of the digestive system } \\
\hline Males & $5.8 * *$ & -2.8 & 1.0 * \\
\hline Females & 4.5 * & $-5.5 *$ & -0.6 \\
\hline Total & $5.3 * *$ & -3.9 & 0.3 \\
\hline \multicolumn{4}{|c|}{ Diseases of the nervous system } \\
\hline Males & 1.9 & -0.9 & -0.6 \\
\hline Females & -1.7 & 1.2 & 2.5 \\
\hline Total & -0.2 & -0.3 & 0.1 \\
\hline \multicolumn{4}{|c|}{ Endocrine, nutritional and metabolic diseases } \\
\hline Males & -0.9 & 1.2 & 0.8 \\
\hline Females & $-9.6 * *$ & 3.1 * & -0.7 \\
\hline Total & $-5.5 * *$ & 1.8 & -0.4 \\
\hline \multicolumn{4}{|c|}{ External causes of morbidity and mortality } \\
\hline Males & 1.0 & $-3.5 * *$ & $-2.5 * * *$ \\
\hline Females & -4.1 & $-3.7 *$ & $-4.0 * \star *$ \\
\hline Total & -0.3 & -3.6 ** & $-2.9 * \star \star$ \\
\hline \multicolumn{4}{|c|}{ Congenital malformations, deformations and chromosomal abnormalities } \\
\hline Males & 3.6 & -3.8 & -0.9 \\
\hline Females & -3.9 * & 7.5 & 5.6 \\
\hline Total & 0.1 & 0.4 & 4.9 \\
\hline \multicolumn{4}{|c|}{ Symptoms, signs and abnormal clinical and laboratory findings, not elsewhere classified } \\
\hline Males & 12.7 & -5.8 * & 3.6 \\
\hline Females & 7.0 * & -3.9 & $3.9 * *$ \\
\hline Total & 10.3 & $-5.5 * *$ & 3.2 \\
\hline
\end{tabular}

$* p<0.05$

** $p<0.01$;

$* * * p<0.001$. 


\section{Figure 1}

Potential years of life lost (PYLL) per 100,000 aged 0-69 years according to selected causes of death. Slovak Republic, 2004-2013.

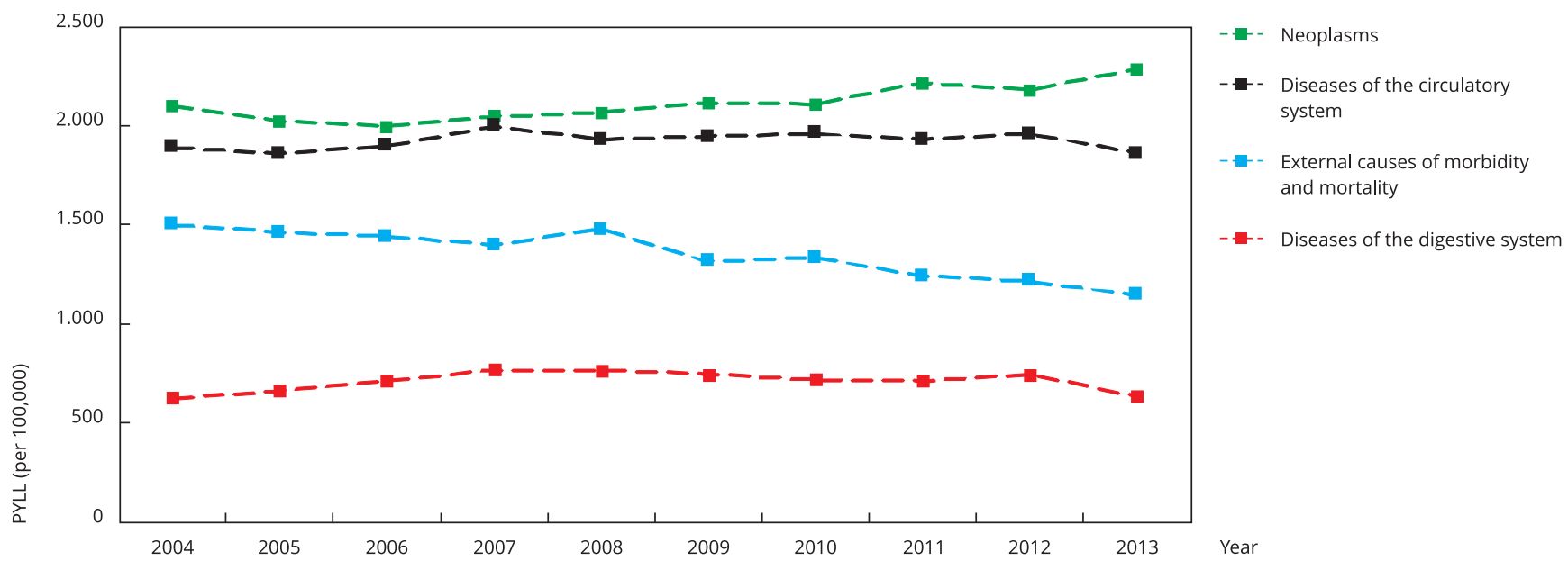

\section{Figure 2}

Potential years of life lost (PYLL) per 100,000 aged 0-69 years according to selected causes of death. Slovak Republic, 2004-2013.

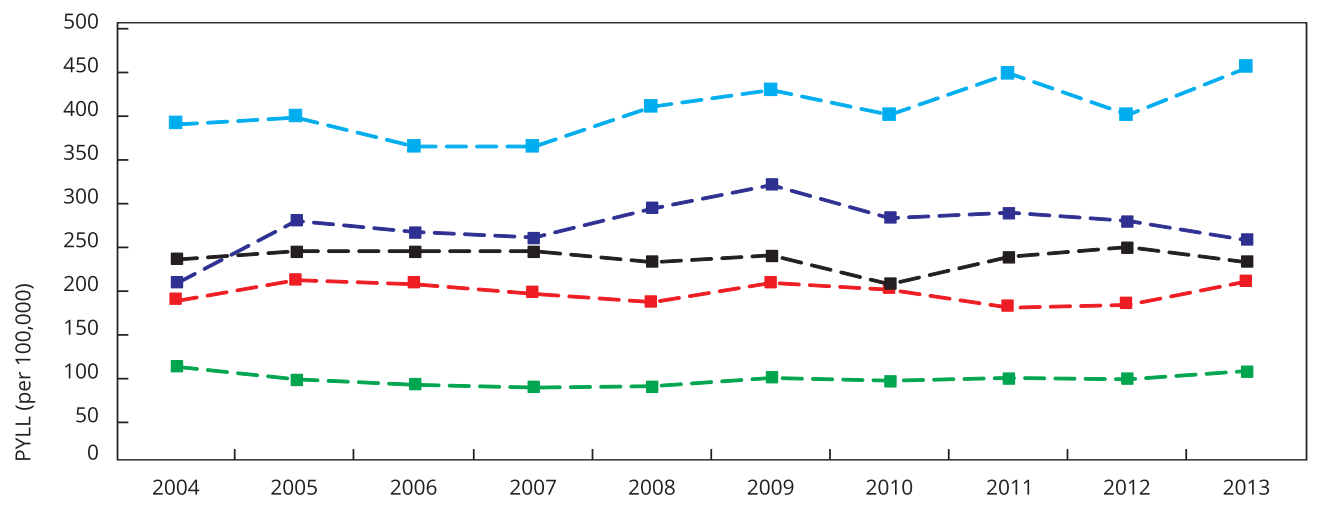

Endocrine, nutritional and metabolic diseases

- Diseases of the nervous system

-1- Diseases of the respiratory system

- - Congenital malformations, deformations and chromosomal abnormalities

- - Symptoms, signs and abnormal clinical and laboratory findings, not elsewhere classified

The PYLL rates trend regarding external causes of morbidity and mortality showed the most notable decrease in the whole assessed period (Figure 1) and the AAPC of PYLL showed significant negative values both in males $(-2.5 \%$; $<0.001)$ and females $(-4 \% ; \mathrm{p}<0.001)$ (Table 1$)$. 


\section{Discussion}

The PYLL indicator is a summary measure of premature mortality, providing an explicit way of weighting deaths occurring at younger ages, which may be preventable 16,17.

From recent OECD data, the total PYLL rate in the Slovak Republic in 2013 was 4,602 per 100,000 aged 0-69, with a more marked decrease since 2008 due to steadily (but still unsatisfactorily) increasing of life expectancy at birth. Within our immediate neighbors, a lower PYLL rate in the same year was found in Austria $(2,842$ per 100,000) and in the Czech Republic (3,618 per 100,000), and a higher one in Poland $(4,901$ per 100,000) and in Hungary $(5,160$ per 100,000) 17.

Neoplasms are one of the leading causes of morbidity and mortality worldwide 16,18. Malignant tumors mortality peaked in the late 1980s in Europe and thereafter has declined 19. In most countries, survival has improved for many types of cancer because of earlier diagnosis and better treatment 9 . Cancer mortality is consistently higher for men than for women in all countries, including Slovakia. The Slovak Republic, together with Hungary, Slovenia and Denmark bear the highest cancer mortality burden, with rates in excess of 240 per 100,000 inhabitants ${ }^{9}$. In the Slovak Republic, death rate for malignant tumors is the second leading cause of death, but the mean total PYLL rate concerning neoplasms was the highest during the observed ten-year period (2004-2013), with a significant upward trend in both genders. Similar results can be seen in some other European countries: e.g. malignant tumors were found as the most common cause of PYLL rate in Spain 20.

According to the latest data from the Slovak National Cancer Registry, the incidence rates indicate increase of cancer cases for both genders, but mainly among females. The rapid increase and large occurrence in males are caused mainly by colorectal, lung and prostate cancers. Hungary and Slovakia had the highest colorectal cancer mortality in 2013 among all OECD countries. In females, the dramatic increase of the overall number of cancer cases was primarily caused by breast cancer, non-melanoma skin cancer, female genital organs, colorectal and lung cancers 9,11. This trend concurs with the highest long-term PYLL rate due to neoplasms in females causing high premature female mortality.

Despite substantial decline in recent decades, CVD remain the main cause of mortality in most countries, with prominence of CVD deaths in males. The 2013 Global Burden of Disease Study estimated that almost $30 \%$ of all deaths worldwide were caused by CVD. However, recent evidence from Europe suggests that in some countries and/or regions cancer has overtaken CVD as the leading cause of death 3,21. Better treatment of life-threatening conditions such as heart attack and stroke has led to lower CVD mortality rates in most developed countries.

The most common long-term causes of death in the Slovak Republic are CVD 22. However, the total mean PYLL rate for this disease was not the highest in the observed ten-year period. Out of the 34 OECD countries, the Slovak Republic occupies the last position in standardized CVD mortality. The country has the highest age-standardized mortality rates per 100,000 inhabitants for both ischemic heart disease and cerebrovascular disease among all OECD countries as well 9, which can be explained by high prevalence of common risk factors, mainly high blood pressure. The age-standardized death rate for CVD has decreased in the Slovak Republic since 2004, nevertheless, it is still 50\% higher compared to the average standardized death rate in the European Union (58\% higher in men and $43 \%$ higher in women) 23 . Concurring with these data, a higher mean PYLL rate in the analyzed period was observed in males (2,397 per 100,000) compared with females $(1,449$ per 100,000).

Respiratory system diseases in the developing world are a major burden in terms of morbidity and mortality and, particularly as related to chronic respiratory disease, are of increasing concern. For many years, the leading cause of adult respiratory disease mortality worldwide had been tuberculosis. Currently, tuberculosis mortality rate in the Slovak Republic is extremely low (standardized death rate of 0.3 per 100,000 in 2013). However, respiratory system diseases are the third most frequent case of death (not only in the Slovak Republic but also in the whole European Union, with an average mortality rate of 88 per 100,000 population) in both genders 24 , referring mainly to the diagnosis of pneumonia (despite the widely available antibiotic treatment) 12. Slovakia is one of the European Union countries with the highest mortality rate from pneumonia (37.0 and 17.6 per 100,000 for men and women, respectively) 25 . Respiratory diseases are age-related and the vast majority of deaths are reported in people aged 65 or over. Despite contributing to a relatively small number of PYLL and low number of years of life lost, a significant increase in the PYLL rate regarding respiratory diseases in 
both males and females has been seen in the Slovak Republic, while the opposite trend was observed in Poland 3,26.

Alcohol use is associated with numerous harmful health and social consequences, not only about increased risk of a range of cancers and stroke, but also alcoholic liver disease, chronic hepatitis, liver fibrosis and cirrhosis, which are the most frequent causes of death among digestive system diseases 9,14. The Slovak Republic observed a slightly lower pure alcohol consumption in 2013 (9.9L per capita 15+) than the average alcohol consumption in the European Union (10.1L per capita 15+). However, the first analyzed sub-period (2004-2008) shows a rising alcohol consumption, while an opposite trend can be observed in the second sub-period (2009-2013) 26. This development in alcohol consumption copies the curve of liver diseases mortality, as well as AAPC of PYLL regarding digestive system diseases: a significant increase in the first sub-period followed by a decrease (significantly in females) in the second sub-period.

Hundreds of millions of people worldwide are affected by neurological disorders. Moreover, the extension of life expectancy and the ageing of the general population in both developed and developing countries are likely to increase the prevalence of many chronic and progressive physical and mental conditions, including neurological disorders 27 . Rising mortality from mental and neurological diseases, which is much more pronounced in women, is seen in most European countries, mainly related to rising mortality from dementias (in high-income countries), although this trend have probably been affected by changes in cause-of-death classification. Mortality from psychoactive substance use and Parkinson's disease has also risen in several countries 28 . The Slovak population aged 0-69 years, in the analyzed period, showed an increase (although insignificant) of AAPC of PYLL rate of $2.5 \%$ concerning nervous system diseases in females (in males an insignificant decrease in the same period was observed). This could correlate with a longer life expectancy at birth in females and a large gap in life expectancy between women and men (7.2 years in 2013). Recognizing dementia as a cause of death, and/or refraining from life-saving treatment for patients with the disease appears to be strongly dependent on cultural values 28 .

External causes of death pose the most serious life hazard for young people and contribute to the greatest number of PYLL. External causes of mortality are critical for understanding an injury event and identifying intervention opportunities. Very early in the history of International Classification of Diseases, external causes of injury were seen as crucial for injury prevention purposes 29 . External causes are the fourth leading cause of deaths in the Slovak Republic with a strong prominence of males (standardized death rate 119.6 per 100,000 in males vs. 43.0 per 100,000 in females) 30. Males are known to be more at risk of suicide (in the Slovak Republic, as well as in Poland, men are seven times more likely to commit suicide than women), more prone to stress and alcohol abuse, and are willing to seek help, which is particularly apparent in Central European Countries 9,31. However, the AAPC of PYLL regarding external causes showed a high significant decrease in the observed ten-year period in both males and females, especially in the second 5-year sub-period 2009-2013. Despite these positive trends, the Slovak Republic rank among the European countries with the highest standardized death rate from external causes of mortality 30 .

Data quality, mistakes in reporting primary diagnosis (multiple causes of death) and verbal autopsy could be limitations to death data use for national mortality.

\section{Conclusion}

In this study, trends of PYLL rates per 100,000 and AAPC of PYLL (\%) in the period of ten years 20042013 in the Slovak population aged 0-69 years were analyzed using data from more than 378,535 causes of death. These statistical indicators provide a systematic analysis of premature deaths at a population level and are an important component for identifying health problems where a greater public health attention is required. Comprehensive and comparable data on a population health status are important for health policy decision-making processes. Burden of premature mortality in the Slovak Republic is attributable to chronic non-communicable diseases, primarily malignant tumors (with a significant increasing ten-year trend of PYLL) and cardiovascular diseases (significant decreasing trend of PYLL only in females), and external causes of mortality (with significantly 
decreasing trend of PYLL), followed by digestive and respiratory system diseases (the latter showed significantly increasing trend of PYLL). These main causes of premature death are associated to well known risk factors, which are largely well preventable. However, our findings are limited to mortality and do not provide any information on the burden regarding non-fatal health outcomes. Our results should contribute in developing intervention programs aimed at reducing the burden of premature mortality.

\section{Contributors}

K. Hirosova and L. Argalasova participated on data analysis and interpretation. M. Samohyl and J. Jurkovicova contributed substantially to study design, interpretation and writing of the final version for publication.

\section{Additional informations}

ORCID: Martin Samohyl (0000-0001-6581-2294); Lubica Argalasova (0000-0002-8908-3441); Katarina Hirosova (0000-0003-2655-3714); Jana Jurkovicova (0000-0002-0892-5572).

\section{Conflict of interests}

The authors declare no conflict of interests.

\section{References}

1. Joel GR. Reducing premature mortality among young and middle-aged adults. Health Promot Chronic Dis Prev Can 2017; 37:27-32.

2. Nalini M, Oranuba E, Poustchi H, Sepanlou SG, Pourshams A, Khoshnia M, et al. Causes of premature death and their associated risk factors in the Golestan Cohort Study, Iran. BMJ Open 2018; 8:e021479.

3. Bryła M, Pikala M, Maniecka-Bryła I. Years of life lost due to premature mortality in a province with the shortest life expectancy in Poland. Cent Eur J Public Health 2016; 24:156-62.

4. Stanciak J, Hirner I, Vareckova L. Management of geriatric care and pharmacotherapy. Zdorovja Nacii 2017 ; 42:46-52.

5. Krzyżak M, Maślach D, Szpak A, Piotrowska K, Florczyk K, Skrodzka M, et al. Trends of potential years of life lost due to main causes of deaths in urban and rural population in Poland, 2002-2011. Ann Agric Environ Med 2015; 22:564-71.

6. Kalakun L, Bozzetti MC. Evolution of uterine cervical cancer mortality from 1979 to 1998 in the State of Rio Grande do Sul, Brazil. Cad Saúde Pública 2005; 21:299-309.

7. Bucholz EM, Normand SL, Wang Y, Ma S, Lin $\mathrm{H}$, Krumholz HM. Life expectancy and years of potential life lost after acute myocardial infarction by sex and race: a cohort-based study of Medicare beneficiaries. J Am Coll Cardiol 2015; 66:645-55.

8. Organisation for Economic Co-operation and Development. OECD Health Statistics 2015 frequently requested data. http://www.oecd. $\mathrm{org} /$ health/health-systems/Table-of-ContentMetadata-OECD-Health-Statistics-2015.pdf (accessed on 08/Jul/2016).

9. Organisation for Economic Co-operation and Development. Health at a glance. Paris: OECD Publishing; 2015.

10. GBD 2016 Mortality Collaborators. Global, regional, and national under-5 mortality, adult mortality, age-specific mortality, and life expectancy, 1970-2016: a systematic analysis for the Global Burden of Disease Study 2016. Lancet 2017; 390:1084-150.

11. Sebekova K, Krivosikova Z, Gajdos M, Podracka L. Vitamin D status in apparently healthy medication-free Slovaks: association to blood pressure, body mass index, self-reported smoking status and physical activity. Bratis Lek Listy 2016; 117:702-9. 
12. The Institute of National Health Information Center. Health statistics yearbook of the Slovak Republic 2013. Bratislava: The Institute of National Health Information Center; 2015.

13. Fleiss JL. Statistical methods for rates and proportions. New York: John Wiley \& Sons; 1973.

14. Clegg LX, Hankey BF, Tiwari R, Feuer EJ, Edwards BK. Estimating average annual per cent change in trend analysis. Stat Med 2009; 28:3670-82.

15. Sen PK. Estimates of regression coefficient based on Kendall's tau. J Am Stat Assoc 1968; 63:1379-89.

16. Vohlonen I, Bäckmand H, Korhonen J. Potential years of life lost. The PYLL rate in monitoring the wellbeing of a population. http://www. ndphs.org/documents/2662/Vohlonen\%20 Ilkka\%20PYLL_article_2007.pdf (accessed on 12/Dec/2016).

17. Organisation for Economic Co-operation and Development. Potential years of life lost (indicator). https://data.oecd.org/healthstat/po tential-years-of-life-lost.htm\#indicator-chart (accessed on 02/Sep/2016).

18. Pou SA, Tumas N, Coquet JB, Niclis C, Román MD, Díaz MD. Burden of cancer mortality and differences attributable to demographic aging and risk factors in Argentina, 1986-2011. Cad Saúde Pública 2017; 33:e00016616.

19. Marković-Denić L, Vlajinac H, Živković S, Miljuš D. Cancer mortality among men in Central Serbia: 1985-2006 Survey Study. Croat Med J 2008; 49:792-8.

20. del Valle Gómez MO, López González ML, Arcos González PI, Cueto Espinar A. An analysis of the potential years of life lost to cancer in Asturias and Spain. Rev Sanid Hig Publica (Madr) 1993; 67:129-43.

21. Bhatnagar P, Wickramasinghe K, Williams J, Rayner M, Townsed N. The epidemiology of cardiovascular disease in the UK 2014. Heart 2015; 101:1182-9.

22. Svihrova V, Barakova A, Szaboova V, Kamensky G, Hudeckova H. Trends in standardized mortality rates for select groups of cardiovascular diseases in Slovakia between 1980 and 2010. Public Health 2015; 130:43-50.
23. Kamensky G, Simkova I, Rus V, Avdicova M, Barakova A, Strachotova S. Country report Slovakia - June 2015. https://www.escar dio.org/static_file/Escardio/Subspecialty/ EACPR/Country\%20of\%20the\%20month/ Documents/slovakia-country-of-the-monthfull-report.pdf (accessed on 12/Dec/2016).

24. Eurostat. Causes of death statistics. https:// ec.europa.eu/eurostat/statistics-explained/in dex.php?title=Causes_of_death_statisti_cs/sk (accessed on 09/Jul/2019).

25. Marshall DC, Goodson RJ, Xu Y, Komorowski M, Shalhoub J, Maruthappu M, et al. Trends in mortality from pneumonia in the Europe Union: a temporal analysis of the European detailed mortality database between 2001 and 2014. Respir Res 2018; 19:81.

26. European Health Information Gateway. SDR, diseases of circulatory system, all ages, per 100,000. http://data.euro.who.int/hfadb/ta bles/tableA.php?w=1366\&h=768 (accessed on 02/Sep/2016).

27. World Health Organization. Neurological disorders: public health challenges. Copenhagen: World Health Organization; 2006.

28. Mackenbach JP, Karanikolos M, Looman CW. The rise of mortality from mental and neurological diseases in Europe, 1979-2009: observational study. BMC Public Health 2014; 14:840.

29. McKenzie K, Fingerhut L, Walker S, Harrison A, Harrison JE. Classifying external causes of injury: history, current approaches, and future directions. Epidemiol Rev 2012; 34:4-16.

30. The Institute of National Health Information Center. Health statistics yearbook of the Slovak Republic 2014. Bratislava: The Institute of National Health Information Center; 2016.

31. Pikala M, Bryla M, Bryla P, Maniecka-Bryla I. Years of life lost due to external causes of death in the Lodz Province, Poland. PLoS One 2014; 9:968. 


\section{Resumo}

O estudo teve como objetivo avaliar as tendências nas taxas de anos potenciais de vida perdidos (APVP) na população eslovaca e a análise da variação percentual anual média (VPAM) nas taxas de APVP de acordo com as causas de óbito mais comuns no período de 2004 a 2013. A mortalidade nacional e os dados demográficos foram obtidos do Escritório de Estatística da República Eslovaca. Foram analisadas 378.535 causas de óbito entre 2004 e 2013. Para constituir os valores anuais, foram tabelados, em todas as faixas etárias, os valores de APVP em ambos gêneros e em cada categoria nosológica. Para a análise de tendências, foi proposto o indicador da VPAM. A taxa de APVP é padronizada para a idade e expressa como a soma de todos os óbitos por 100 mil. No periodo de 2004 a 2013, as médias mais altas de APVP foram observadas em neoplasias na população geral (2.103 por 100 mil) e na população feminina (2.088 por 100 mil), com um aumento significativo na VPAM dos APVP em ambos os gêneros. A segunda maior média de APVP no período de 10 anos foi devida a doenças cardiovasculares, tanto na população geral (1.922 por 100 mil) quanto na população feminina (1.449 por 100 mil). Na população masculina, as doenças cardiovasculares tiveram a maior taxa de APVP (2.397 por 100 mil). A tendência nas taxas de APVP por causas externas mostraram a redução mais importante no período avaliado, e a VPAM dos APVP comprovou os valores negativos significativos, tanto em homens $(-2,5 \% ; p<0,001)$ quanto em mulheres $(-4 \% ; p<0,001)$. Os resultados devem contribuir para o desenvolvimento de intervenções voltadas para a redução da carga de mortalidade prematura, considerando que as principais causas de morte prematura estão associadas a fatores de risco bem conhecidos e preveníveis.

Anos Potenciais de Vida Perdidos; Tendências; Mortalidade Prematura; Causas de Morte

\section{Resumen}

El objetivo de este estudio fue evaluar las tendencias de las tasas de los años potenciales de vida perdidos (PYLL por sus siglas en inglés) en la población eslovaca y el análisis de la variación promedio del porcentaje anual (AAPC por sus siglas en inglés) de las tasas PYLL, de acuerdo con las causas más comunes de muerte, durante el período de 2004-2013. La mortalidad nacional y los datos demográficos se obtuvieron de la Oficina Estadística de la República Eslovaca; se analizaron 378.535 causas de muerte entre 2004 y 2013. Los valores de PYLL en ambos géneros y en cada categoría de enfermedad se contaron en todos los grupos de edad para formar valores anuales. Para el análisis de tendencia, se propuso el indicador AAPC. La tasa de PYLL se encuentra estandarizada por edad y expresada como la suma de todas las muertes por 100.000. En el período 2004-2013, las tasas medias más altas de PYLL se observaron en neoplasias en toda la población (2.103 por 100.000), así como en las mujeres (2.088 por 100.000) con un incremento significativo permanente alto de la AAPC en los PYLL en ambos géneros. La segunda tasa media más alta de PYLL, durante el período de diez años, se debió a las enfermedades del sistema circulatorio en total (1.922 por 100.000), al igual que en las mujeres (1.449 por 100.000). En hombres, las enfermedades del sistema circulatorio tienen la tasa más alta de PYLL (2.397 por 100.000). La tendencia de las tasas de PYLL, debida a causas externas de morbilidad y mortalidad mostró un notable decremento en el período evaluado y la AAPC de PYLL probaron los valores negativos significativos tanto en hombres (-2,5\%; $p$ $<0,001)$ como en mujeres $(-4 \%$; $p<0,001)$. Nues tros resultados deberían contribuir al desarrollo de la intervención en programas que tengan como meta reducir la carga de la mortalidad prematura, considerando que las causas principales de muerte prematura están asociadas a factores de riesgo bien conocidos y prevenibles.

Años Potenciales de Vida Perdidos; Tendencias; Mortalidad Prematura; Causas de Muerte
Submitted on 15/Mar/2018

Final version resubmitted on 15/Jul/2019

Approved on 08/Oct/2019 